\title{
The Editorial History of a Rare and Forbidden Franciscan Book of the Italian Renaissance: The Dialogo della Unione Spirituale di Dio con l'anima by Bartolomeo Cordoni
}

\author{
Michele Camaioni
}

The early decades of the Cinquecento witnessed a proliferation of religious publications in the Italian vernacular. In the second half of the century the Council of Trent (1545-1563) and the founding of the Roman Congregations of the Holy Office (1542) and of the Index (1572) would halt the consistent and substantially uncontrolled development of devotional and spiritual literature. But in the generation before this a huge number of pamphlets and books, "from the more traditional to the more innovative", flooded the markets of the Italian peninsula, with considerable impact on the religious thought and practice of both clergy and laypeople. ${ }^{1}$ As has been pointed out, spiritual books acted in those years, alongside with popular preaching, as effective vehicles for religious propaganda and for the dissemination of new ideas. ${ }^{2}$ They promoted not only the doctrines introduced by the German and Swiss Reformation, but also the anti-dogmatic spirituality and the reform proposals elaborated by Italian evangelical groups clustered around such leading figures as the Venetian cardinal Gaspare Contarini and the Spanish alumbrado Juan de Valdés, or by the representatives of the most dynamic religious gatherings of the age, from

1 For an overview on this topic, see Ugo Rozzo, Linee per una storia dell'editoria religiosa in Italia (1465-160o) (Udine: Arti Grafiche Friulane, 1993); Edoardo Barbieri, 'Tradition and Change in the Spiritual Literature of the Cinquecento', in Gigliola Fragnito (ed.), Church, Censorship and Culture in Early Modern Italy (Cambridge: Cambridge University Press, 2001), pp. 111-133; Gabriella Zarri, Libri di spirito. Editoria religiosa in volgare nei secoli $X V-X V I I$ (Turin: Rosenberg \& Sellier, 2009).

2 Cf. Robert W. Scribner, For the Sake of Simple Souls. Popular Propaganda for the German Reformation (Cambridge: Cambridge University Press, 1981); Corrie E. Norman, 'The Social History of Preaching: Italy', in Larissa Taylor (ed.), Preachers and People in the Reformations and Early Modern Period (Leiden: Brill, 2001), pp. 125-191; Andrew Pettegree, Reformation and the Culture of Persuasion (Cambridge: Cambridge University Press, 2005). 
the lay confraternity of the Divino Amore to the new religious Orders of the Barnabites, the Jesuits and the Capuchins. ${ }^{3}$

Closely connected to the early development of the Capuchins is the printing of one of the most intriguing mystical booklets of the European Renaissance period, the Dialogo della unione spirituale di Dio con l'anima by Bartolomeo Cordoni. Despite the censorship of the Roman and Spanish Inquisitions, from the 1530 s the book went through several editions in Italy and in Spain and continued to circulate until the first half of the seventeenth century. Its complex editorial history, which this article will attempt to reconstruct, represents a meaningful case of 'editorial longevity' and deserves, for this reason, specific attention. ${ }^{4}$

The book was written by the Observant Franciscan mystic Bartolomeo Cordoni from Città di Castello, a former follower of the humanist Angelo Poliziano. Cordoni was a member of that rigorist movement which, at the beginning of the sixteenth century, promoted the reform of the Order of the Friars Minor through asceticism and hermitic contemplation, inspiring Spanish alumbradism and Italian pre-quietism. ${ }^{5}$ Published for reasons of prudence after the death of its author in 1535 , the Dialogo della unione is undoubtedly an heterodox text, since it combines the radical spiritualism of the Franciscan tradition, with the neoplatonic mysticism of the Mirror of the

3 Cf. Christopher F. Black, Italian Confraternities in the Sixteenth Century (Cambridge: Cambridge University Press, 1989); Euan Cameron, 'Italy', in Andrew Pettegree (ed.), The Early Reformation in Europe (Cambridge: Cambridge University Press, 1992), pp. 188-214; Richard L. DeMolen (ed.), Religious Orders of the Catholic Reformation. In Honor of John C. Olin on His Seventy-Fifth Brithday (New York: Fordham University Press, 1994); Constance M. Furey, Erasmus, Contarini, and the Religious Republic of Letters (Cambridge: Cambridge University Press, 2006); Diana Robin, Publishing Women. Salons, the Presses, and the CounterReformation in Sixteenth-Century Italy (Chicago: The University of Chicago Press, 2007), pp. 41-101; Massimo Firpo, Juan de Valdés and the Italian Reformation (Aldershot: Ashgate, 2015).

4 Ugo Rozzo, Biblioteche italiane del Cinquecento tra Riforma e Controriforma (Udine: Arti Grafiche Friulane, 1994), p. 157.

5 Cf. Paola Zambelli, 'Bartolomeo di Castello', in Dizionario Biografico degli Italiani (Rome: Istituto dell'Enciclopedia Italiana, 1960-), vol. 6 (1964), pp. 707-708. On the spread of Franciscan spiritualism in Italy and Spain at the beginning of the sixteenth century, see Michele Camaioni, 'Libero spirito e genesi cappuccina. Nuove ipotesi e studi sul Dyalogo della unione spirituale di Dio con l'anima di Bartolomeo Cordoni e sul misterioso trattato dell'Amore evangelico', Archivio Italiano per la Storia della Pietà, 25 (2012), pp. 303-372, at pp. 330-333. On Franciscan radicalism between fifteenth and sixteenth centuries, cf. Duncan Nimmo, Reform and Division in the Franciscan Order (Rome: Istituto Storico dei Cappuccini, $\left.1995^{2}\right)$, pp. $637-658$. 
Simple Souls by Marguerite Porete. This masterpiece of the Mediaeval heresy of Free Spirit was condemned by the Roman Church in 1311-1312 at the Council of Vienne. ${ }^{6}$ As scholars have shown, several chapters of the Dialogo della unione are translations into Italian of Marguerite's Mirror. According to Catholic theologians the main doctrinal error of this work was to assume that through ascetic contemplation, mystical annihilation and illumination, the human soul could reach a status of impeccability, perfect union and oneness with God during earthly life. ${ }^{7}$

The first edition of Cordoni's book was published in Perugia in 1538 under the Latin title De unione anime cum supereminenti lumine and the direction of the Franciscan Observant Ilarione Pico da Borgo San Sepolcro (ill. 12.1). ${ }^{8}$ A disciple of Bartolomeo Cordoni, friar Ilarione obtained a printing licence from the cardinal legato of Perugia, Marino Grimani, and softened the text of the Dialogo to avoid the suspicion of begardism, that is the heresy of the Free Spirit. ${ }^{9}$

A few months later, on 10 January 1539, a second and uncensored edition of the Dialogo appeared in Milan under the title Dyalogo de la unione spirituale di Dio con l'anima..$^{10}$ As we learn from the dedicatory letter, this edition was

6 Cf. Paolo Simoncelli, 'Il "Dialogo dell'unione spirituale di Dio con l'anima" tra alumbradismo spagnolo e prequietismo italiano', Annuario dell'Istituto Storico Italiano per l'Età Moderna e Contemporanea, 29-30 (1977-1978), pp. 565-601; Costanzo Cargnoni, 'Fonti, tendenze e sviluppi della letteratura spirituale cappuccina primitiva', Collectanea Franciscana, 48 (1978), pp. 311-398; Stanislao da Campagnola, 'Bartolomeo Cordoni da Città di Castello e le due prime edizioni del suo "Dialogo", Bollettino della Deputazione di Storia Patria per l'Umbria, 80 (1983), pp. 89-152. On the of circulation of radical spiritual texts in Franciscan Italian libraries, see Roberto Rusconi, 'La tradizione manoscritta delle opere degli Spirituali nelle biblioteche dei predicatori e dei conventi dell'Osservanza', Picenum Seraphicum, 12 (1975), pp. 63-137. For an overview, cf. David Burr, The Spiritual Franciscans. From Protest to Persecution in the Century After Saint Francis (University Park: The Pennsylvania State University Press, 2001).

7 Cf. Sean L. Field, Robert E. Lerner and Sylvain Piron (eds.), Marguerite Porete et le Miroir des simples âmes. Perspectives historiques, philosophiques et litteraires (Paris: Vrin, 2013). See also Joanne M. Robinson, Nobility and Annihilation in Marguerite's Porete's Mirror of Simple Souls (Albany: State University of New York Press, 2001).

8 Bartolomeo da Castello, De unione anime cum supereminenti lumine. Opera nuova et utile ad ogni fidel christiano. Composta per il reverendo padre frate Bartholomeo da Castello. De l'ordine de l'observantia (Perugia: nelle case di Girolamo Cartolari; ad instantia de mastro Antonio Pasini, 1538); octavo, ff. 136 (CNCE 4476).

9 Cf. Campagnola, 'Bartolomeo Cordoni', pp. 114-117, 130-137.

10 Bartolomeo da Castello, Dyalogo de la unione spirituale de Dio con l'anima dove sono interlocutori l'amor divino, la sposa anima, et la ragione humana (Milan: per Francesco Cantalupo \& Innocenzo Cicognara, 10 January 1539); 16mo, ff. [12] 271 [1] (CNCE 4477). 


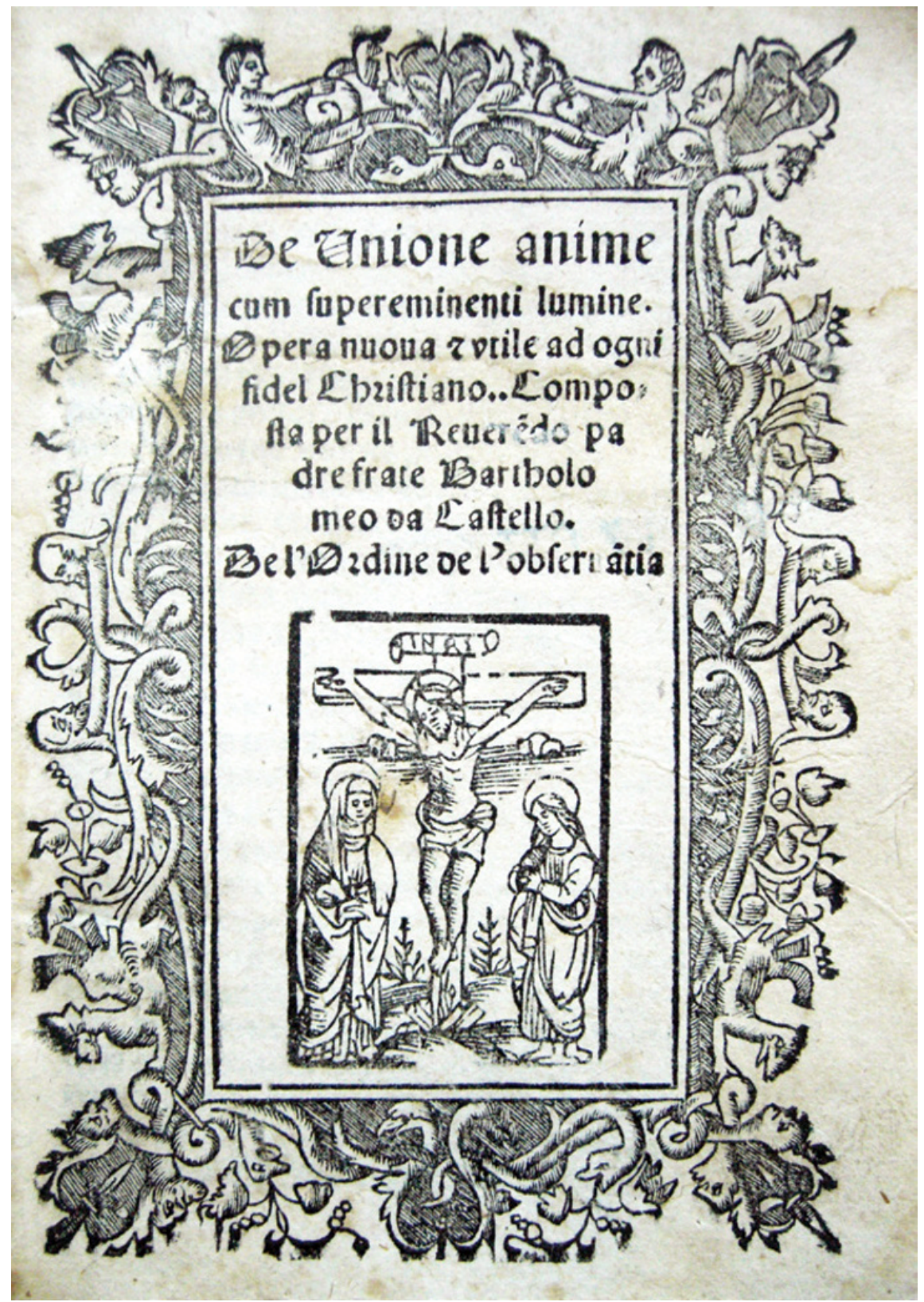

ILLUSTRATION 12.1

Bartolomeo da Castello, De unione anime cum supereminenti lumine

(Perugia: Girolamo Cartolari; ad instantia de Antonio Pasini, September $1538)$

(C) Pontificium Athenaeum Antonianum, Rome [Rari 0091]. 
prepared by the Capuchin friar Girolamo Spinazzola da Molfetta, a collaborator of the vicar-general of the Order, Bernardino Ochino, well known for his flight from Italy to Calvin's Geneva in 1542 at the time of the founding of the Roman Holy Office. ${ }^{11}$ Another difference between the 'Observant' edition (Perugia, 1538) and the 'Capuchin' (Milan, 1539), can be seen in the number of chapters. Whereas the 'Observant' edition is composed of 52 chapters, the 'Capuchin' edition includes an additional chapter, entitled Circolo de carità divina [Circle of divine charity]. This esoteric text, which in the 1580 s would have attracted the attention of the Roman Inquisition for the novum et insolitum orandi modum ("the new and unusual manner of praying") it prescribed, was probably written not by Cordoni himself, but by the friar Francesco Ripanti da Iesi, a prominent figure among the Capuchins during the 1530 and 1540 os. $^{12}$

It is worth explaining that the Capuchin Order had been founded some years earlier, in 1525, by a small group of reformed Observant friars and wandering preachers who wanted to restore the pure and strict observance of the Franciscan Rule. ${ }^{13}$ The birth of the Capuchin Order was the result of an unexpected schism in Franciscan Observance, a powerful institution which, thanks to the bull Ite vos issued by Pope Leo $\mathrm{x}$ a few years earlier in 1517, had incorporated all existing local reforms and had obtained the legal precedence over the Conventuals within the Order of the Friars Minor. ${ }^{14}$ This suggests that the publishing of two different editions of Cordoni's Dialogo, one by the Observants and one by the Capuchins, could be linked to the struggle for pre-eminence within the Franciscan Order, which in the 1530 s was still raging in Italy.

11 Cf. Delio Cantimori, Eretici italiani del Cinquecento (Florence: Sansoni, 1939); Roland H. Bainton, Bernardino Ochino esule e riformatore senese del Cinquecento (1487-1563) (Florence: Sansoni, 1940); John Tedeschi, James M. Lattis and Massimo Firpo (eds.), The Italian Reformation of the Sixteenth Century and the Diffusion of Renaissance Culture: A Bibliography of the Secondary Literature (Ca. 1750-1997) (Ferrara: Panini, 2000), pp. $361-378$.

12 See Campagnola, 'Bartolomeo Cordoni', pp. 117-119; Costanzo Cargnoni, 'Complessità teologiche e ascendenze spirituali del "Circolo de carità divina" di Francesco Ripanti da Iesi', Collectanea Franciscana, 60 (1990), pp. 615-663; Bert Roest, Franciscan Literature of Religious Instruction before the Council of Trent (Leiden: Brill, 2004), p. 419; Giorgio Caravale, Forbidden Prayer. Church Censorship and Devotional Literature in Renaissance Italy (Aldershot: Ashgate, 2011), pp. 109-110.

13 Cf. Melchior a Pobladura, Historia generalis Ordinis Fratrum Minorum Capuccinorum. I: 1525-1619 (Rome: Institutum Historicum Ord. Fr. Min. Cap., 1947); Costanzo Cargnoni (ed.), I frati cappuccini. Documenti e testimonianze del primo secolo, 5 vols. (Perugia: Edizioni Frate Indovino, 1988-1993).

14 Cf. Pacifico Sella, Leone X e la definitiva divisione dell'Ordine dei Minori (OMin.): La bolla "Ite vos" (29 maggio 1517) (Grottaferrata: Frati Editori di Quaracchi, 2001). 
Previous studies of Cordoni's Dialogo assumed unanimously that the two described editions of the book were the only ones printed before the opening of the Council of Trent in 1545. A survey of recent studies on the dispersed collections of books owned by Italians humanists and an unexpected discovery in a Franciscan library in Rome, however, allow us to present here two previously unknown editions of the Dialogo which were probably printed between 1539 and the first half of the $1540 \mathrm{os}$. Both editions show the dedicatory letter of Girolamo da Molfetta and their internal structure is close to that of the Capuchin edition of Milan. ${ }^{15}$

The first of these two new editions was published in Naples on 24 December 1539, by Johann Sultzbach, printer in 1537 of the Capuchins' Constitutions (ill. 12.2) ${ }^{16}$ It survives in a unique copy, now at the British Library in London. ${ }^{17}$ It was identified thanks to a footnote reference by Massimo Danzi in his work dedicated to the history of the library of the famous humanist and cardinal Pietro Bembo. ${ }^{18}$

The other lost and now found edition of the Dialogo is more challenging and problematic, since it is published without date or imprint (ill. 12.3) ${ }^{19}$ Only four copies survive. The copy I have examined is in the library of the Pontifical University Antonianum in Rome, whose catalogue wrongly listed it as the Milanese edition of 1539. By an analysis of the watermark and by the comparison with other texts of the period we can argue that this edition appeared in Northern Italy, presumably in Venice, between 1539 and the following years. ${ }^{20}$

15 Cf. Camaioni, 'Libero spirito', p. 309.

16 Bartolomeo da Castello, Dialogo della unione spirituale de Dio con l'anima dove sono interlocutori l'Amor divino, la Sposa Anima, et la Ragione humana (Naples: per Johann Sultzbach, 24 December 1539); 80, ff. 220. On the editor, see Pietro Manzi, Annali di Giovanni Sultzbach (Napoli, 1529-1544; Capua, 1547) (Florence: Olschki, 1970).

17 London, British Library, shelfmark R.B.23.a.3427. The book did not appear on the online catalogue of the library, but was identified with the help of Mr Stephen Parkin, curator of the Italian Printed Collections (1501-1850), to whom goes my warm thank.

18 See Massimo Danzi, La biblioteca del cardinal Pietro Bembo (Geneva: Droz, 2005), p. 314.

19 Bartolomeo da Castello, Dyalogo della unione spirituale de Dio con l'anima dove sono interlocutori l'Amor divino, la Sposa Anima et la Ragione humana (s.l.: s.n, s.d.); 16mo, ff. 148 (CNCE 77517).

20 The watermark appears similar to that of two models reproduced in Briquet's repertoire ("Oiseau inscrit dans un cercle"; "Ancre inscrite dans un cercle surmontée d'una étoile"). See Charles-M. Briquet, Les Filigranes. Dictionnaire historique des Marques du Papier (Hildesheim-Zürich-New York: Georg Olms Verlag, 1991), nn. 12215, 12221; 484, 485, 496, 520. See also Nicola Barone, Le filigrane delle antiche cartiere ne' documenti dell'Archivio di Stato in Napoli (Naples: Francesco Giannini \& Figli, 1889), p. 96. Further investigations would be required on this topic. 


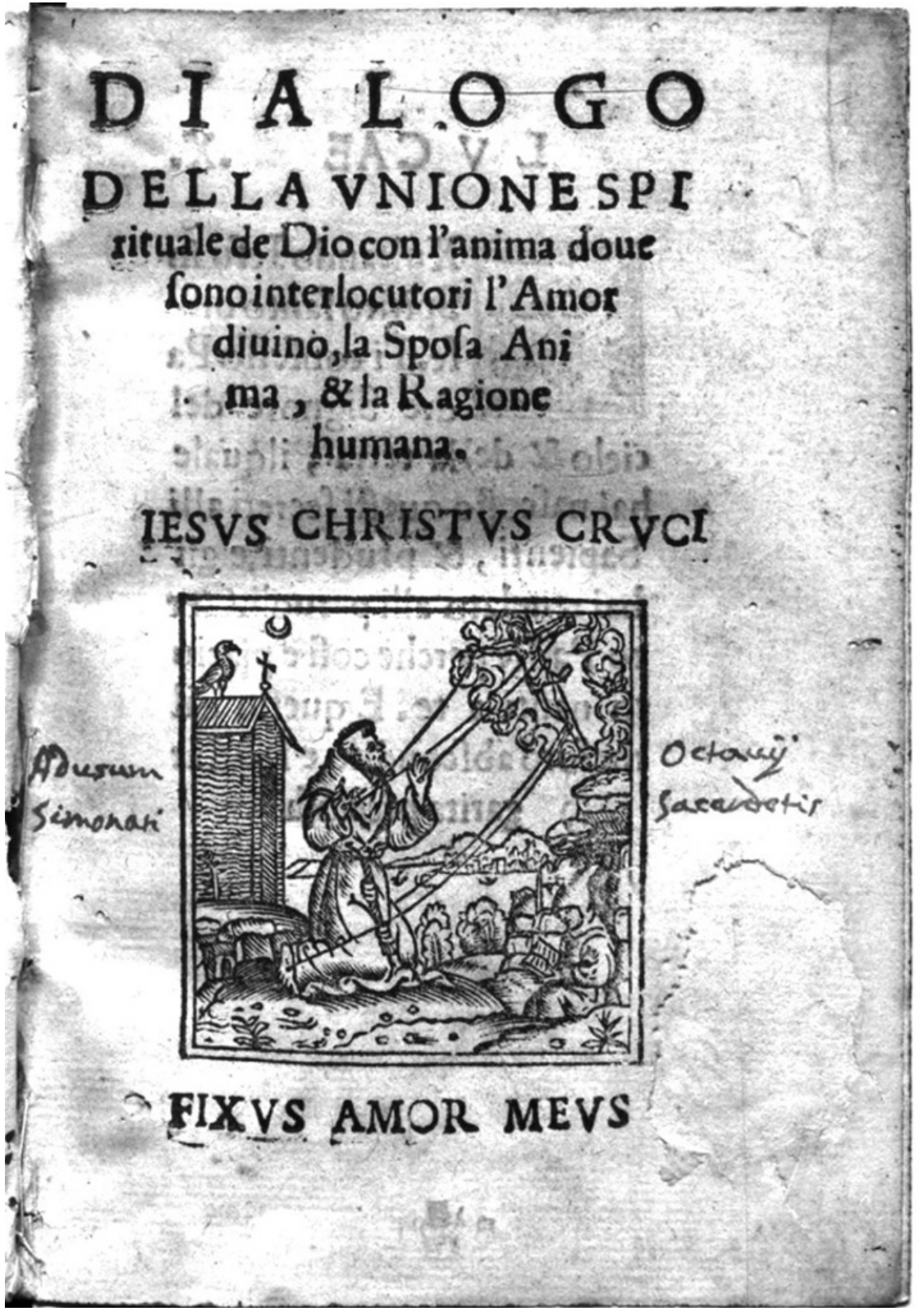

illustration 12.2 Bartolomeo da Castello, Dialogo della unione spirituale de Dio con l'anima (Naples: per Johann Sultzbach, 24 December 1539) (c) British Library [R.B.23.a.3427]. 
The same hypothesis has been advanced by the librarians of the Bavarian State Library of Munich, where two further copies of this edition are conserved. ${ }^{21}$ The assumption is based, inter alia, on the observation that the title page of this edition of Cordoni's Dialogo shows the same xylography with Christ on the Cross surrounded by the Virgin Mary and John the Apostle that we find on two printed spiritual treatises which circulated in that period in the Venetian area. The first is an undated edition of Tullio Crispoldi's De la santissima communione, a popular treatise on the sacrament of the Holy Eucharist first printed in 1535 in Venice. ${ }^{22}$ The second is an anonymous undated spiritual book entitled Trattato de gli tre discorsi sopra il gaudio, dolore, et gloria, per il quale si camina allaperfettione dell'anima, now in a miscellany of the Bayerische Staatsbibliothek bound with works of Crispoldi and with the very same undated edition of Cordoni's Dialogo. ${ }^{23}$ The edition of Crispoldi's Eucharistic treatise can be found in the Capuchins' Provincial Archive of Assisi, where it is part of an interesting sextodecimo miscellany composed of works written by Crispoldi himself and by the already mentioned Girolamo da Molfetta. ${ }^{24}$

The discovery of these two lost editions of the Dialogo is of great interest for historians of Italian religious dissent of the Renaissance period, because it allows us to shed new light on an unknown feature of the editorial strategy employed by the first Capuchins and Bernardino Ochino, the leading personality among the Order, in their effort to influence the public debate and the agenda of the Catholic Church in these critical years which witnessed the

21 According to Edit16, a further copy of this edition is owned by the Biblioteca Comunale of Terni, a small town in the Umbria region, in Central Italy.

22 Tullio Crispoldi, De la santissima comunione (Venice: per Stefano Nicolini da Sabbio, August 1535); octavo, ff. 44 (CNCE 50676).

23 Munich, Bayerische Staatsbibliothek [Bavarian State Library], cod. Mor. 248. The Bavarian State Library owns a second copy of the Trattato de gli tre discorsi, included in the miscellany signed Asc. 4951. This miscellany contains, among other texts of religious education, an edition of Crispoldi's De la santissima communione (Venice: Vittore Ravani, 1540). See Camaioni, 'Libero spirito', pp. 313-314.

24 Assisi, Archivio Provinciale Cappuccino, cod. 8-1-18: 1) Tullio Crispoldi, Simplici erudimenti over ammaestramenti della fede nostra christiana, raccolti per Tullio Crispoldo da Riete ([Venice]: per Stefano Nicolini da Sabbio, 1539); 2) Tullio Crispoldi, Della santissima communione con la esortazione al frequentare e il rispondere alle contrarie obiettioni (s.l.: s.n., s.d.); 3) Exhortatione al frequentare la sanctissima communione. Con rispondere alle contrarie obiettioni, (s.l.: s.n., s.d.); 4) [Girolamo da Molfetta], Tavola per la dottrina de la religione christiana di tutte quelle cose che ciascuno è tenuto di sapere. Novamente corretta et illustrata (s.l.: s.n., April 1540); 5) Tullio Crispoldi, Alcune pratiche del viver christiano (Venice: per Stefano Nicolini da Sabbio, 1538); 6) Tullio Crispoldi, Alcuni rimedi appresso a le pratiche del viver christiano (Venice: per Stefano Nicolini da Sabbio, 1538). 


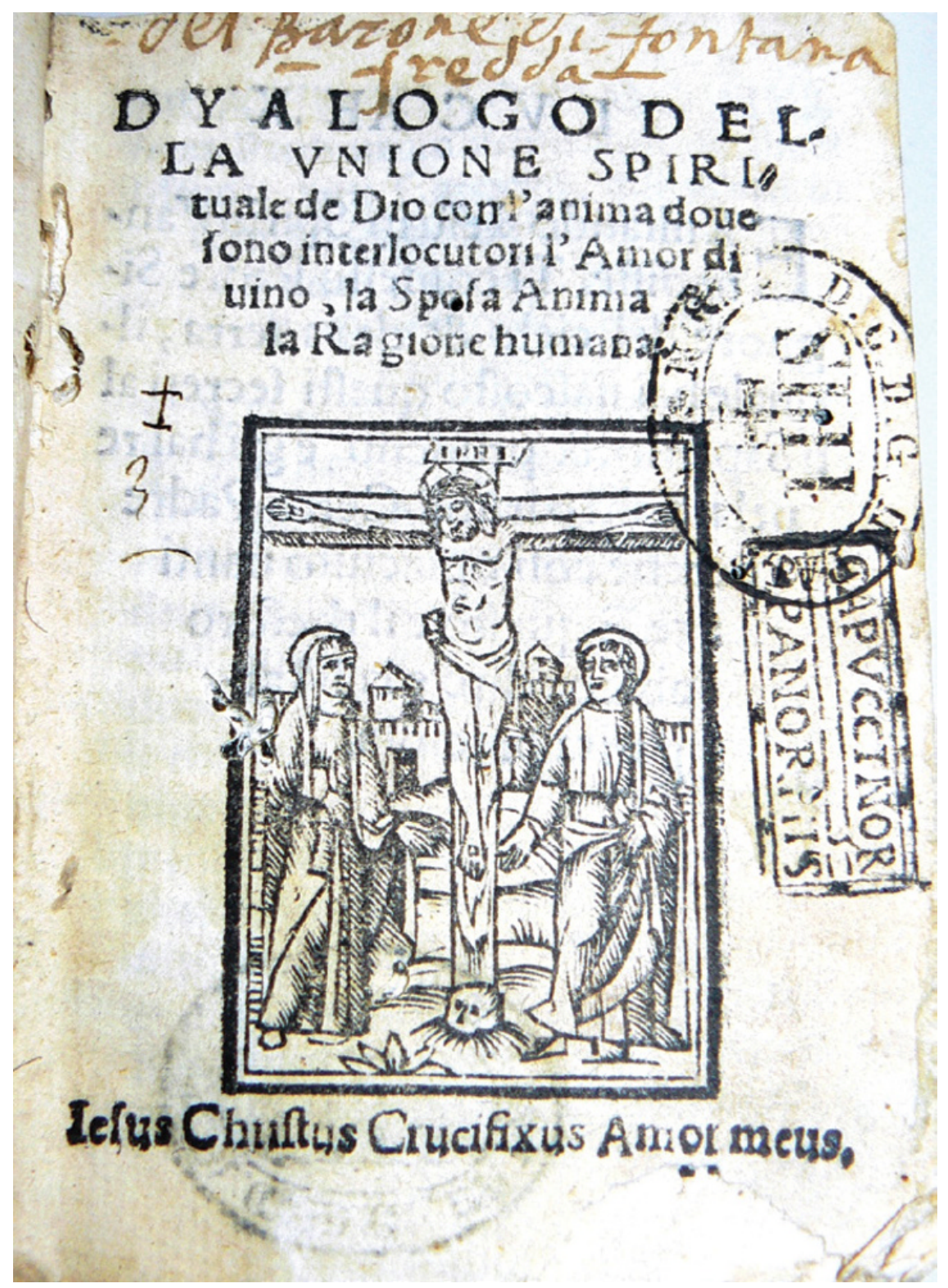

illustration 12.3 Bartolomeo da Castello, Dyalogo della unione spirituale de Dio con l'anima (s.l.d.)

(C) Pontificio Ateneo Antonianum, Rome [Rari 0361]. 
decisive confrontation between different reform movements within the Roman Curia and of the convocation the Council of Trent. ${ }^{25}$

Two lost books have been re-discovered, but the editorial history of Cordoni's work is not thereby concluded. The Dialogo della unione, indeed, was printed again in 1546 in Barcelona, where a Catalan version circulated under the title Dialogo del amor de Deu. ${ }^{26}$ This Catalan edition, which was the a translation of the Observant edition printed in Perugia in 1538, was soon banned by the Spanish and Portuguese Inquisitions. ${ }^{27}$ Notwithstanding this clear signal of orthodox disapprobation, new Italian editions of the book were published in 1548 in Venice, in 1589 in Bologna and in 1593 once more in Venice..$^{28}$ It is worth noting that the last two editions mentioned, those of 1589 and 1593 , were printed when the Dialogo della unione had already been prohibited by the Roman Church.

In the first years after its foundation in 1542, the Holy Office had been forced to face the danger represented by the widespread diffusion of Reformed ideas in the Italian peninsula, paying for this reason scarce attention to the rise of other forms of heterodox spirituality. In the last decades of the century and especially from 1572, when the Congregation of the Index flanked the Roman Inquisition in the cultural and religious battle for the affirmation of the ideals of Catholic Counter-Reformation, many of the spiritual vernacular books printed in the first half of the sixteenth century fell under suspicion.

25 Cf. Massimo Firpo, Valdesiani e spirituali. Studi sul Cinquecento religioso italiano (Rome: Edizioni di Storia e Letteratura, 2013); John J. Martin, 'Renovatio and Reform in Early Modern Italy', in Ronald K. Delph, Michelle M. Fontaine and John J. Martin (eds.), Heresy, Culture, and Religion in Early Modern Italy. Context and Contestations (Kirksville, мо: Truman State University Press, 2006), pp. 1-17.

26 Bartolomeo da Castello, Dialogo del amor de Deu (Barcelona: Joan Carles Amorós, 1546).

27 See Jesús M. De Bujanda (ed.), Index de l'Inquisition espagnole 1551, 1554, 1559, Index des livres interdits, vol. v (Geneva: Droz, 1984), pp. 472-473; Jesús M. De Bujanda (ed.), Index de l'Inquisition espagnole 1583, 1584, Index des livres interdits, vol. vi (Geneva: Droz, 1993), p. 589; Jesús M. De Bujanda (ed.), Index de l'Inquisition portugaise 1547, 1551, 1564, 1581, Index des livres interdits, vol. IV (Geneva: Droz, 1995), p. 475; Iveta Nakladova, 'La censura del Diálogo de la unión del alma con Dios', in Roger Friedlein (ed.), Diálogo y censura en el siglo XVI (Madrid: Iberoamericana Vervuert, forthcoming).

28 Bartolomeo da Castello, Dialogo de la unione spirituale de Dio con l'anima (Venice: per Pietro Nicolini da Sabbio, 1548); sextodecimo, ff. 216 (CNCE 4478); Bartolomeo da Castello, De unione anime cum Deo (Perugia: per Girolamo Cartolari, 1538. Et ristampata in Bologna: per Fausto Bonardo, 1589); octavo, ff. 136 (CNCE 4479); Bartolomeo da Castello, Dialogo dell'unione spirituale di Dio con l'anima. Opera di grandissimo frutto, a persone spirituali, \& a peccatori. Di nuovo ristampata, e più corretta (Venice: appresso Bartolomeo Carampello, 1593); octavo, ff. 164 (CNCE 4480). 
In 1576 , the Dialogo della unione was listed in an unpublished catalogue of suspect books drafted by the priest Giovanni di Dio at the request of Cardinal Guglielmo Sirleto. ${ }^{29}$ Four years later, in 1580 , Cordoni's work was included in the local lists of forbidden books issued in Parma and Alessandria-Tortona. ${ }^{30}$ In 1584, finally, the Roman Holy Office issued a decree which condemned the Dialogo della unione and the Circolo de la carità divina as heretical texts. ${ }^{31}$ The decision, which was probably based on the censure of the book compiled by the Capuchin friar Evangelista Ferratina da Cannobio, was confirmed some years later with the inclusion of the Dialogo della unione in the unpromulgated Roman Indices of 1590 and $1593^{32}$

The title of Cordoni's mystical book does not however appear in the Index issued in 1596 by Clement VIII. The reason for this temporary exclusion of the Dialogo from the list of the books forbidden by the Catholic Church can be found in the ambitious attempt by the Congregation of the Index in those years to distinguish between books that had to be absolutely banned and others which should be forbidden quamdiu expurgantur or donec corrigentur: that is, until they were amended by a censor and therefore restored to their role of useful instruments of religious instruction, moral disciplining and spiritual growth. ${ }^{33}$

In pursuit of this goal, the Congregation of the Index set up a broad inquiry into the libraries of the religious Orders in all of the Italian Provinces. An examination of the surviving lists of this investigation, preserved in the Vatican Library, reveals that despite the condemnation of the Roman Inquisition, at the end of the sixteenth century several Italian convents owned a copy of one of the editions

29 Caravale, Forbidden Prayer, pp. 107-108.

30 Cf. Ugo Rozzo, La strage ignorata. I fogli volanti a stampa nell'Italia dei secoli XV e XVI (Udine: Forum, 2008), p. 195 .

31 Vatican, Archivio della Congregazione per la Dottrina della Fede (Archive of the Roman Congregation for the Doctrine of the Faith; hereafter: ACDF), Archivio del Sant'Officio, Decreta, 1584, cc. nn.; Archivio della Congregazione dell'Indice (Index), Diari I, Registrum actorum et decretorum Sacrae Congregationis Indicis ab anno 1571 [ad annum] 1606, c. 14V; Index, Protocolli A, c. 87. A printed edition of this decree (Rome: heirs of Antonio Blado, 1584 ) is published by Simoncelli, 'Il “Dialogo della unione", pp. 6oo-6o1.

Jesús M. De Bujanda, Ugo Rozzo, Peter G. Bietenholz and Paul F. Grendler (eds.), Index de Rome 1590, 1593, 1596. Avec étude des index de Parme 1580 et Munich 1582, Index des livres interdits, vol. IX (Geneva: Droz, 1994), p. 112. On Evangelista da Cannobio's censures, see Caravale, Forbidden Prayer, pp. 114-121. On the Index of 1590 and 1593, see Gigliola Fragnito, Proibito capire. La Chiesa e il volgare nella prima età moderna (Bologna: Il Mulino, 2005), pp. 43-45; Vittorio Frajese, Nascita dell'Indice. La censura ecclesiastica dal Rinascimento alla Controriforma (Brescia: Morcelliana, 2006), pp. 131-147.

33 Cf. Fragnito, Proibito capire, passim; Frajese, Nascita dell'Indice, pp. 177-220, 271-315; Caravale, Forbidden Prayer, pp. 123-146. 
of Cordoni's heterodox mystical book. Many Franciscan nunneries and friaries of the Umbria region retained copies of the Observant edition of the Dialogo della unione printed in Perugia in 1538, and the Capuchins of the Province of Lombardia kept at least a copy of the Venetian edition printed in 1593. The libraries of the Province of Siracusa in Sicily contained two copies of a work listed as Dialogo del divino amore by Girolamo da Molfetta, which can be identified as one of the Capuchin editions of Cordoni's Dialogo della unione. Evidently, towards the close of the sixteenth century the Dialogo was still a popular book among the Capuchin friars who had inherited Cordoni's spiritual legacy. ${ }^{34}$

Nevertheless, from the beginning of the seventeenth century the possession of the Dialogo della unione once again became risky for its owners. The book was condemned and banned by the Roman Church in 1600 and in 1603. The decision was taken after the cardinals of the Holy Office had read the appraisal undertaken by a Capuchin friar, Girolamo Mautini da Narni on the orders of the Congregation of the Index. In his handwritten censure, Mautini accused the author of the Dialogo della unione of being an "heresiarch", who had drawn on the ancient doctrines "of Begards and Beguines" and made a worst error than Luther, since he pretended "to make men Gods" ("fare gli huomini Dei"). ${ }^{35}$

34 See the RICI database by the project on Le biblioteche degli ordini regolari in Italia alla fine del secolo XVI, online: <http://rici.vatlib.it>. On this project, see also Rosa Marisa Borraccini and Roberto Rusconi (eds.), Libri, Biblioteche e Cultura degli ordini regolari nell'Italia moderna attraverso la documentazione della Congregazione dell'Indice (Vatican: Biblioteca Apostolica Vaticana, 2006). For Cordoni's dialogue occurrence in the lists provided by the Capuchins - which still have not been poured in RICI's database - see Stanislao da Campagnola, Le biblioteche dei Cappuccininel passaggio tra Cinque e Seicento, in Anselmo Mattioli (ed.), Biblioteche Cappuccine Italiane (Perugia: Biblioteca Oasis, 1988), pp. 65-105, now also in Stanislao da Campagnola, Oratoria sacra. Teorie ideologie biblioteche nell'Italia dei secoli XVI-XIX (Rome: Istituto Storico dei Cappuccini, 2003), pp. 350-395, at pp. 330, 374, 380-382; Costanzo Cargnoni, 'Libri e biblioteche dei Cappuccini della provincia di Siracusa alla fine del sec. XvI', Collectanea Franciscana, 77 (2007), pp. 63-151, at p. 96, 137, 141. See also Ugo Rozzo, Le biblioteche dei cappuccini nell'inchiesta della Congregazione dell'Indice (1597-1603), in Vincenzo Criscuolo (ed.), Girolamo Mautini da Narni e l'ordine dei Cappuccini fra '50o e '6oo (Rome: Istituto Storico dei Cappuccini, 1998), pp. 57-101; Vincenzo Criscuolo, 'Il catalogo delle biblioteche dei conventi cappuccini della Provincia di Milano alla fine del Cinquecento', Laurentianum, 44 (2003), pp. 391-516; Giovanna Granata, Le biblioteche dei cappuccini in Umbria alle soglie del '6oo, in Vincenzo Criscuolo (ed.), I cappuccini nell'Umbria del Seicento (Rome: Istituto Storico dei Cappuccini, 2003), pp. 243-270. di Dio con l'anima, ff. $2 r-42 r$. The codex of this handwritten Censura is in Rome, Biblioteca Casanatense, ms. 345 . 
Mautini's censure was delivered on 29 January 1600 to the Cardinals of the Congregation of the Index, who decided to condemn the Dialogo della unione, confirming their decision with a decree on 7 August $1603 .{ }^{36}$

In the same years, the Roman Inquisition determined to investigate the Venetian 1593 edition of the Dialogo. This edition, probably to avoid censorship and licence regulation, was published with a false attribution of authorship. On its title page the author is named as "Bartolomeo da Città di Castello, Capucino", while he had been, as we have seen, an Observant friar. This detail was finally noticed by members of the Holy Office, who in 1599 ordered their Venetian commissario to investigate the printer Bartolomeo Carampello and the circumstances that led to the the false attribution of authorship. ${ }^{37}$ We do not know the outcome of this inquiry. It is tempting to suggest a connection with the "long drawn-out struggle" between the Venetian printing industry and the Roman Inquisition, that arose in the second half of the sixteenth century as a consequence of the publications of the various editions of Roman Index librorum prohibitorum. ${ }^{38}$

To round off this brief account on the editorial history of Cordoni's Dialogo della unione, we need to proceed into the seventeenth century. In 1647, after almost fifty years of silence on the matter, the Roman Congregation of the Index was forced to pay new attention to the forbidden Dialogo della unione. ${ }^{39}$ From the documents preserved in the Vatican Archive of the Congregation for the Doctrine of the Faith we find that in those years an anonymous book entitled Dialogo abbreviato dell'unione di Dio con l'anima appeared in Italy. This

36 Cf. Jesús M. De Bujanda (ed.), Index librorum prohibitorum 1600-1966, Index des livres interdits, vol. XI (Montréal-Geneva: Médiaspaul-Droz, 2002), pp. 198-199. See also Zambelli, "Bartolomeo di Castello", p. 708.

$37 \mathrm{ACDF}$, Index, Diari I, f. 129r; Index, Registrum litterarum vulgarium et latinarum scriptae Sacrae Congregationis Indicis ab anno 1582 usque 1602, ff. 119v-120r. See Michele Camaioni, 'Le vicende editoriali del Dialogo della unione spirituale di Dio con l'anima di Bartolomeo Cordoni tra censure preventive e tardivi interventi della congregazione dell'Indice', Schifanoia, 44-45 (2013), pp. 147-16o, at pp. 156-157.

38 The Archive of the Roman Congregation for the Doctrine of the Faith does not indeed give us further information on the inquiry. An investigation into Venice's public archives could, probably, tell us more about it. For an overview on this topic, see Neil Harris, 'The Italian Renaissance Book: Catalogues, Censuses and Survival' in Malcolm Walsby and Graeme Kemp (eds.), The book triumphant. Print in Transition in the Sixteenth and Seventeenth centuries (Leiden: Brill, 2011), pp. 26-56, p. 29; Paul F. Grendler, The Roman Inquisition and the Venetian Press 1540-1605 (Princeton: Princeton University Press, 1977).

39 In the meanwhile, the Dialogo della unione had been included in the Roman Index of forbidden books released in 1632: cf. De Bujanda, Index librorum prohibitorum 160o-1966, pp. 198-199. 
was not good news for the Cardinals of the Index. In the middle of the seventeenth century Roman institutions were considerable exercised by the renewed diffusion of mystical texts: a devotional phenomenon which some years later, in the second half of the century, would inspire the new spiritualist heresy of quietism.

In 1647 the Secretary of the Congregation of the Index Gian Battista de Marini, a Dominican friar, ordered the censorship of this mysterious Dialogo abbreviato dell'unione. No reference to this book can be found in catalogues and book lists of this period. It is a lost book, but not completely. Two reports compiled by the priest Antonio Giani and now kept in the Protocolli series of the Vatican Archive of the Congregation for the Doctrine of the Faith, allow us to partially reconstruct the text of this book, which appears to have been an anthology, a short compilation of selected extracts taken from the Dialogo della unione by Bartolomeo Cordoni. ${ }^{40}$

The censor himself realized that there was a connection between the Dialogo abbreviato and the Dialogo dell'unione by Cordoni: "They are of the same flour", he wrote. ${ }^{41}$ For this reason, he decided to dust down Girolamo da Narni's censure of the Dialogo dell'unione from 1599-160o, and to employ its structure, based on the identification of 15 "Paradoxes of the union" (i.e. doctrinal errors), to censor the new Dialogo abbreviato. ${ }^{42}$ The Dialogo abbreviato was finally condemned as a text which renewed the ancient heresy of the Free Spirit: "I think that for the listed mistakes, without considering the others contained in it, the book should be burnt and put among the madcap ones", concluded the censor. ${ }^{43}$ So we now know that a collection based on the Dialogo della unione circulated in Italy in the 1640 s, and it has been possible to reconstruct significant passages on the basis of the censures found in the Archive of the Congregation of the Faith.

What, more generally, Cordoni's case shows, is that the attention paid by the Catholic Church to the development of forms of mysticism and spirituality which overstepped the permitted doctrinal boundaries was intermittent until the 1570s; at this point, when the establishment of Protestant churches in the Italian peninsula was no longer a serious threat, the Roman congregations could turn their attention towards other forms of cultural and religious dissent.

\footnotetext{
40 ACDF, Index, Protocolli H H, f. 106r-113v.

41 Ibid., f. $108 r$.

42 Ibid., ff. $108 v-113 v$.

43 "Crederei che il libro per li detti errori, tralasciati gli altri in esso contenuti, si potesse abbrugiare e numerare fra pazzerelli”: ACDF, Index, Protocolli н н, f. 107r.
} 
Nevertheless, despite the repeated condemnations by the Holy Office and the Congregation of the Index, the Dialogo della unione di Dio con l'anima was printed again in 1593 and continued to be read in Franciscan convents throughout the first half of the seventeenth century. Finally, in 1647 the defenders of Roman orthodoxy discovered a compilation of Cordoni's work and censored it, underlining the close connection between the original Dialogo della unione and this lost booklet, which most likely contributed to paving the way for the spread of the quietist heresy in the Italian peninsula. ${ }^{44}$

44 Cf. Massimo Petrocchi, Il quietismo italiano del Seicento (Rome: Edizioni di storia e letteratura, 1948); Adelisa Malena, L'eresia dei perfetti. Inquisizione romana ed esperienze mistiche nel Seicento italiano (Rome: Edizioni di storia e letteratura, 2003). 